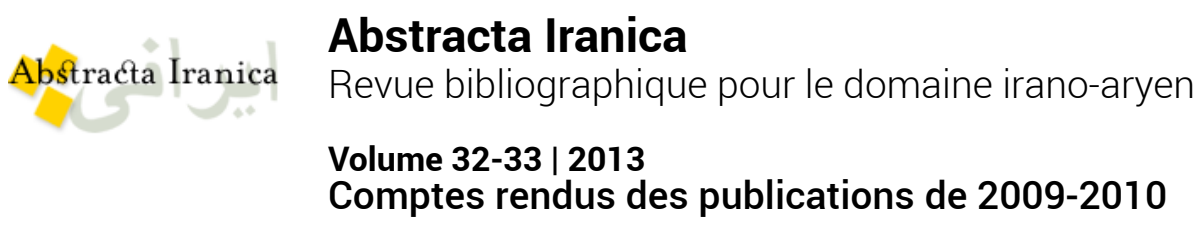

\title{
Philippe Luisier. Tables des matières des tomes I à L
}

Christelle Jullien

\section{(2) OpenEdition}

Journals

Édition électronique

URL : http://journals.openedition.org/abstractairanica/40852

DOI : 10.4000/abstractairanica.40852

ISSN : 1961-960X

Éditeur :

CNRS (UMR 7528 Mondes iraniens et indiens), Éditions de l'IFRI

Édition imprimée

Date de publication : 1 décembre 2013

ISSN : 0240-8910

\section{Référence électronique}

Christelle Jullien, « Philippe Luisier. Tables des matières des tomes I à L », Abstracta Iranica [En ligne], Volume 32-33 | 2013, document 335, mis en ligne le 01 juillet 2016, consulté le 05 octobre 2020. URL : http://journals.openedition.org/abstractairanica/40852 ; DOI : https://doi.org/10.4000/ abstractairanica.40852

Ce document a été généré automatiquement le 5 octobre 2020.

Tous droits réservés 


\title{
Philippe Luisier. Tables des matières des tomes I à L
}

\author{
Christelle Jullien
}

\section{RÉFÉRENCE}

Philippe Luisier. Tables des matières des tomes I à L. Turnhout, Brepols, 2008, 99 p.

(Patrologia Orientalis 225)

1 L'A. nous offre un précieux instrument de travail avec ces tables des matières complètes des cinquante tomes de la Patrologia Orientalis, collection de textes chrétiens dans les langues de l'Orient, qui a fêté ses 100 ans d'existence. 4 tables ont été établies : l'une suit l'ordre chronologique des volumes parus; la suivante recense les auteurs anciens et les titres; deux tables alphabétiques, l'une des ouvrages dans l'ordre des langues, l'autre des auteurs modernes et des collaborateurs.

\section{AUTEURS}

\section{CHRISTELLE JULLIEN}

CNRS, Mondes iranien et indien, Paris 